\title{
IMPLEMENTASI MODEL MANAJEMEN PEMBELAJARAN KETERAMPILAN VOKASIONAL UNTUK MENYIAPKAN ANAK TUNAGRAHITA RINGAN MEMASUKI DUNIA KERJA
}

\author{
Rejokirono \\ SLB Pembina Yogyakarta \\ Email: rejokironodr@gmail.com
}

\begin{abstract}
Abstrak
Anak tunagrahita adalah anak yang mengalami hambatan intelektual. Hambatan intelektualnya memberikan tuntutan agar pendidikan bagi mereka ditekankan pada pengembangan potensi keterampilan vokasionalnya agar bisa mandiri. Berdasarkan Peraturan Gubernur DIY Nomor 47 Tahun 2010 SLB memiliki 8 tugas pokok dan fungsi di antaranya adalah penyelenggaraan latihan kerja bagi anak didik berkebutuhan khusus dalam persiapan memasuki dunia kerja. Seharusnya anak tunagrahita lulusan SLB memiliki keterampilan dan memiliki kesiapan memasuki dunia kerja. Namun kenyataan mereka masih menganggur belum diberdayakan di masyarakat. Salah satu penyebabnya karena belum optimalnya pembelajaran keterampilan. Sekolah belum banyak melibatkan pihak orangtua dan pengusaha dalam perencanaan, pelaksanaan dan evaluasi pembelajaran, serta masih minimnya kegiatan magang kerja bagi siswa SMALB. Melalui implementasi model manajemen dengan spesifikasi pengelompokan rombongan belajar berdasarkan jurusan keterampilan; materi keterampilan vokasional berdasarkan analisis kurikulum dari pusat dan disesuaikan dengan masukan/kebutuhan pelaku DUDI; pendekatan proses pembelajaran tematik fungsional dengan tema-tema keterampilan; pelaksanaan PKL dan magang kerja; pelaksanaan kerjasama dengan pelaku Dunia Usaha dan Dunia Industri. Hasil implementasi bahwa telah terlaksana pengelompokan rombongan belajar berdasarkan jurusan keterampilan; materi keterampilan telah disesuaikan dengan masukan atau kebutuhan pelaku DUDI; menggunakan pendekatan tematik dengan tema-tema keterampilan; pelaksanaan PKL dan magang kerja; serta terlaksana kerjasama dengan pelaku DUDI, yang berdampak pada meningkatnya kesiapan anak memasuki dunia kerja dan bertambahnya jumlah anak yang dapat bekerja. Kepada SLB yang ada menyelenggarakan pendidikan bagi anak tunagrahita disarankan untuk secara bertahap dapat menerapkan model manajemen pembelajaran keterampilan untuk menyiapkan anak tunagrahita ringan memasuki dunia kerja ini.
\end{abstract}

Kata kunci: anak tunagrahita, keterampilan vokasional, kemandirian.

\section{Latar Belakang}

Anak tunagrahita adalah anak yang mengalami hambatan intelektual. Hambatan intelektual tersebut memberikan tuntutan agar pendidikan bagi mereka ditekankan pada pengembangan potensi keterampilan vokasional agar bisa mandiri. Ditinjau dari kemampuan intelektual, anak tunagrahita memiliki Intelligence Quotient (IQ) $\leq 70$. Tingkat kemampuan anak tunagrahita tersebut dikelompokkan menjadi tiga yaitu anak tunagrahita ringan (mampu didik) memiliki IQ 51-70, anak tunagrahita sedang atau (mampu latih) dengan IQ 26-50, dan anak tunagrahita berat (mampu latih) dengan IQ $\leq 25$. Penelitian ini fokus pada kelompok anak tunagrahita ringan karena (mampu didik) yang masih sangat memungkinkan untuk dilatihkan keterampilan untuk kemandiriannya.

Berdasarkan Peraturan Gubernur DIY Nomor 47 Tahun 2010 Sekolah Luar Biasa (SLB) memiliki 8 tupoksi di antaranya adalah penyelenggaraan latihan kerja bagi anak didik berkebutuhan khusus dalam persiapan memasuki dunia kerja. Amanah Peraturan Gubernur ini memiliki implikasi bahwa sekolah harus melakukan langkah-langkah strategis 
untuk melaksanakan program-program yang memberikan kesempatan anak tunagrahita ringan berlatih keterampilan, dan menyediakan tempat untuk PKL atau magang kerja. PKL atau magang kerja dimaksudkan untuk memberikan pengalaman langsung bekerja di dunia kerja yang sebenarnya. Fasli Jalal (2011:10) mengatakan bahwa angka lulusan pendidikan menengah maupun perguruan tinggi yang tidak terserap di dunia kerja masih relatif tinggi setiap tahunnya. Untuk menghasilkan lulusan siap pakai, Kemdiknas telah melakukan kerja sama dengan asosiasi. Sejalan dengan itu, Joko Santoso (2011: 15) mengatakan bahwa langkah yang harus dilakukan matching antara dunia pendidikan dan dunia kerja. Di samping itu harus diperbanyak pendidikan vokasi, memberikan keterampilan dan pengalaman kerja. Di sisi lain diharapkan dunia usaha juga memberikan kesempatan kerja bagi anak-anak yang sudah pernah PKL atau magang kerja. pembelajaran keterampilan, serta masih minimnya kegiatan kerja bagi siswa.

Untuk mengatasi permasalahan itu Sekolah Luar Biasa (SLB) Negeri 1 Yogyakarta mengimplementasi model manajemen dengan spesifikasi sebagai berikut: (1) pengelompokan rombongan belajar berdasarkan jurusan keterampilan; (2) penyediaan materi keterampilan vokasional berdasarkan analisis kurikulum dari pusat dan disesuaikan dengan masukan/kebutuhan pelaku DUDI; (3) pendekatan proses pembelajaran tematik fungsional dengan tema-tema keterampilan; (4) pelaksanaan PKL dan magang kerja; (5) kerjasama dengan pelaku DUDI.

Tunagrahita menurut American Psychiatric Association (2013: 36) adalah "Intellectual disability (intellectual developmental disorder) is a disorder with onset during the developmental period that includes both intellectual and adaptive functioning deficits in conseptual,

Tabel 1. Perbandingan Jumlah Jam Pelajaran untuk Mata Pelajaran Keterampilan Vokasional pada Kurikulum 1994, Kurikulum 2006, dan Kurikulum 2013.

\begin{tabular}{llcccccc}
\hline \multirow{2}{*}{ Kurikulum } & Nama Mata Pelajaran & \multicolumn{3}{c}{ Jumlah Jam } & \multicolumn{3}{c}{ Persentase (\%) } \\
\cline { 3 - 7 } & & X & XI & XII & X & XI & XII \\
\hline 1994 & Keterampilan Vokasional/ TIK & 26 & 26 & 26 & 61 & 61 & 61 \\
\hline 2006 & Keterampilan Vokasional/ TIK & 24 & 24 & 24 & 66 & 66 & 66 \\
\hline 2013 & Keterampilan Pilihan & 24 & 26 & 26 & 57 & 59 & 59 \\
\hline
\end{tabular}

Keterangan:

a. Jumlah jam pelajaran keterampilan vokasional berada pada angka 24 - 26 .

b. Untuk persentase berada pada angka $57,14 \%$ sampai dengan $66,67 \%$.

Memperhatikan struktur kurikulum tersebut anak tunagrahita lulusan SLB adalah anakanak yang memiliki keterampilan dan memiliki kesiapan memasuki dunia kerja. Namun kenyataan bahwa lulusan SMALB masih menganggur belum diberdayakan di masyarakat. Hasil penelusuran alumni SLB menunjukkan bahwa 90\% dari jumlah lulusan yang tercatat di dinas Dikpora DIY dalam kondisi menganggur. Permasalahan anak tidak siap memasuki dunia kerja dan menganggur ini disebabkan karena belum optimalnya pelaksanaan model manajemen pembelajaran keterampilan. Sekolah belum melibatkan pihak orangtua dan pengusaha dalam perencanaan, pelaksanaan dan evaluasi pembelajaran social, and and practical domains".

Hambatan intelektual (gangguan perkembangan intelektual) adalah gangguan yang terjadi selama periode perkembangan yang mencakup defisit fungsi intelektual dan adaptif dalam domain konseptual, sosial, dan praktik atau keterampilan. Selanjutnya American Psychiatric Association (2013: 37) menyatakan, "The various levels of severity are devined on the basis of adaptive functioning, and not IQ scores, becauses it is adaptives functioningthat ditermines the level of support required. Moreover, IQ measures are less valid in the lower end of the IQ range." Anak tunagrahita ringan memiliki berbagai istilah tergantung dari sudut pandang para ahli yang 
memberikan definisi tentang anak tunagrahita ringan. Istilah yang sudah umum dipakai dalam pendidikan luar biasa antara lain anak mampu didik, educable, mild, debil dan tunagrahita ringan, Intellectual disability.

Selanjutnya Smith, Ittenbach \& Patton (2002: 43) mengemukakan bahwa People who are mentally retarded over time have been referred to as dumb, stupid, immature, defective, deficient, subnormal, incompetent, and dull. Terms such as idiot, imbecile, moron, and feebleminded were commonly used historically to label this population. Although the word fool referred to those who were mentally ill, and the word idiot was directed toward individuals who were severely retarded, these terms were frequently used interchangeably. Pernyataan di atas mengandung makna bahwa pada waktu yang lalu orang-orang menyebut retardasi mental dengan istilah dungu, bodoh, tidak masak, cacat, kurang sempurna, di bawah normal, tidak mampu, dan tumpul. Istilah lainnya mampue rawat, mampu latih, mampu didik, dan lamban belajar digunakan untuk melabel kelompok penyandang tersebut.

Kondisi anak tunagrahita yang mengalami kelemahan dalam kemampuan berpikir akan mempengaruhi segi kehidupannya. Gangguan yang timbul pada anak tunagrahita antara lain gangguan pada kemampuan kognitif, komunikasi, dan kemampuan dalam merawat diri. Hal ini mengakibatkan mereka menjadi bagian masyarakat yang membutuhkan pendidikan khusus. Hal tersebut sesuai dengan yang dikemukakan Grossman dalam Smith, et al. (2002: 50), "Mental retardation refers to significantly sub average general intellectually functioning existing concurrently with deficits in adaptive behavior, and manifested during the developmental period". Definisi itu mengemukakan dua kriteria dari individu yang dianggap retardasi mental yaitu kecerdasan di bawah rata-rata dan kekurangan dalam adaptasi tingkah laku yang terjadi selama masa perkembangan.

Anak tunagrahita ringan merupakan salah satu dari anak yang mengalami gangguan perkembangan dalam mentalnya mereka memiliki tingkat kecerdasan antara 50-75.
Mereka memiliki kemampuan sosialisasi dan motorik yang baik, dan dalam kemampuan akademis masih dapat menguasai sebatas pada bidang tertentu. Munawir Yusuf, dkk (2003: 19) mengemukakan bahwa anak dengan intelegensi rendah diketahui melalui tes intelegensi. Seseorang yang memiliki IQ di bawah 70 (untuk skala Weschler) disebut tunagrahita.

Berdasarkan pendapat di atas dapat diambil pengertian bahwa anak tunagrahita ringan yaitu mereka yang mempunyai IQ antara 51-70, masih mempunyai potensi untuk berkembang dalam kemampuan akademik di sekolah, dapat dididik keterampilan hidup sehari-hari serta memerlukan program khusus dan bimbingan khusus agar dapat berkembang secara optimal untuk dapat mandiri di masyarakat. Manajemen pembelajaran keterampilan merupakan kegiatan mengelola pembelajaran keterampilan vokasional mulai dari perencanaan, pengorganisasian, pelaksanaan dan evaluasi, yang dilakukan oleh guru dengan melibatkan orangtua dan stakeholder pendidikan lainnya, dengan tujuan untuk membantu peserta didik mencapai tujuan belajarnya. Menurut Rejokirono (2017) program layanan harus bisa mengembangkan potensi yang dimiliki agar bisa berkarya atau bisa diterima bekerja ditempat-tempat usaha dan dapat hidup layak bersama masyarakat di lingkungannya.

Sedangkan menurut Syarifurahman \& Tri Ujiati (2013:71) bahwa antara tujuan, strategi pembelajaran, dan proses penilaian yang digunakan oleh guru selama berlangsungnya proses pembelajaran akan selalu memiliki pengaruh atau saling keterkaitan satu sama lain, dimana tujuan akan mempengaruhi strategi pembelajaran yang akan diterapkan, dan bagaimana teknik penilaian yang tepat agar tujuan dapat tercapai. Muhammad Yaumi (2012:28) menyatakan bahwa hakikat teori pembelajaran adalah untuk menentukan dan menggunakan prinsip-prinsip yang dilakukan oleh pendidik dan pengembang untuk mencapai tujuan pembelajaran. Haerana (2016: 69) menyatakan bahwa: Pembelajaran merupakan proses komunikasi dua arah, mengajar dilakukan oleh guru sebagai pendidik dan belajar dilakukan oleh peserta didik. Guru 
dapat mengajar dengan baik, dan peserta didik dapat belajar dengan baik apabila diantara keduanya ada komitmen untuk menciptakan pembelajaran yang interaktif, inspiratif, menyenangkan, memotivasi pembelajaran yang interaktif, memotivasi peserta didik untuk berpartisipasi aktif, serta memberikan ruang yang cukup bagi prakarsa, kreativitas, dan kemandirian sesuai dengan bakat dan minat dan perkembangan fisik serta psikologis peserta didik.

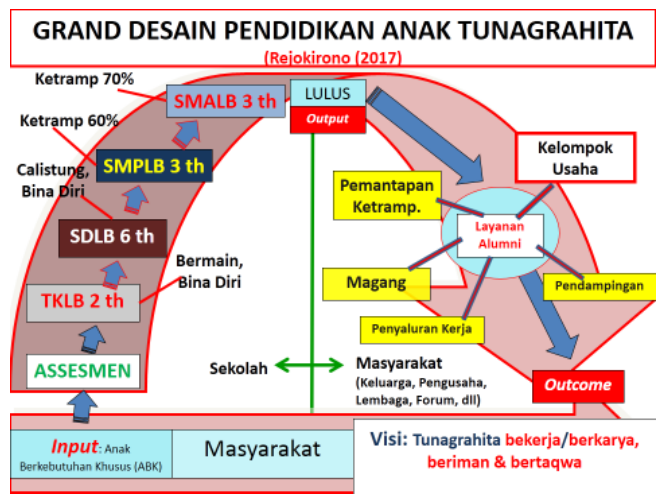

Gambar 1. Grand Desain Pendidikan Anak (Rejokirono, 2017)

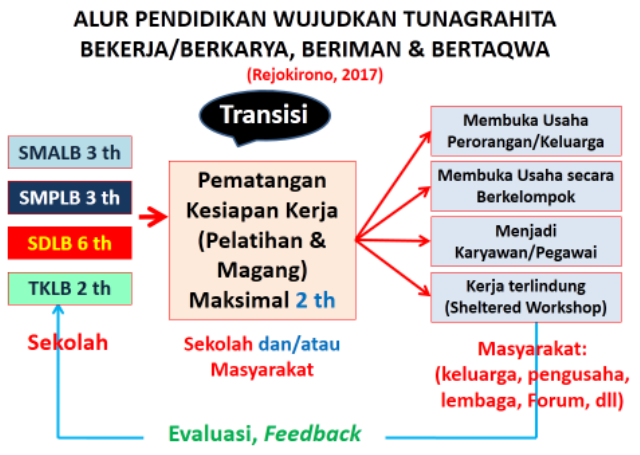

Gambar 2. Alur Pendidikan Anak Tunagrahita (Rejokirono, 2017)

Komponen-komponen pembelajaran yang sekurang-kurangnya meliputi tujuan, materi, alat dan media, metode, evaluasi, guru, peserta didik, dan lingkungan memiliki keterkaitan yang saling mempengaruhi dalam mencapai tujuan pembelajaran. Yulk, G. (1994: 376) menyatakan, “... transformational leaders make followers more aware of the importance and value of task outcomes, artivate their higher order needs, and induce followers to transcend self interest for the sake of the organization". Pemimpin transformasional harus dapat mempengaruhi pengikutnya untuk mengutamakan kepentingan organisasi di atas kepentingan pribadi, dan mengajak tim untuk mencapai kinerja atau prestasi yang lebih tinggi. Pemimpin sangat berperan untuk mewujudkan penerapan model pembelajaran ini agar berjalan dengan baik dan sesuai tujuan untuk meningkatkan kesiapan anak tunagrahita ringan memasuki dunia kerja. Mencermati Gambar 1 terlihat bahwa layanan pendidikan bagi anak tunagrahita didesain berkesinambungan dan terpadu mulai dari Taman Kanak-Kanak Luar Biasa (TKLB), Sekolah Dasar Luar Bias (SDLB), Sekolah Menengah Pertama Luar Biasa (SMPLB), Sekolah Menengah Atas Luar Biasa (SMALB), dan layanan Pasca Sekolah. Pola ini memberikan gambaran bahwa untuk mewujudkan anak tunagrahita yang dapat bekerja atau berkarya harus dipersiapkan sejak dini. Setiap jenjang pendidikan memiliki fokus potensi yang harus dikembangkan.

Gambar 1 menunjukkan bahwa pada TKLB diutamakan pembelajaran dengan pola bermain, SDLB pembelajaran difokuskan pada kompetensi membaca, menulis, dan berhitung; jenjang SMPLB fokus pada kompetensi keterampilan vokasional awal; pada SMALB fokus pengembangan kompetensi keterampilan vokasional, dilanjutkan dengan layanan transisi selama maksimal 2 tahun oleh sekolah, masyarakat, lembaga swadaya masyarakat, dan pihak-pihak lain yang memiliki perhatian terhadap masa depan anak tunagrahita.

Selanjutnya pada Gambar 2 menegaskan bahwa pendidikan harus dikelola secara utuh mulai dari TKLB, SDLB, SMPLB, SMALB, masa transisi, penyaluran ke dunia kerja, dan dilakukan evaluasi secara terus menerus untuk memberikan masukan untuk perbaikan pembelajaran yang akan datang. Kendala yang ditemukan saat anak memasuki dunia kerja akan memberikan masukan untuk perbaikan proses pembelajaran di sekolah. Tampilan pada Gambar 3 menunjukkan bahwa pengelompokan rombongan belajar pada jenjang SMPLB dan SMALB berdasarkan jenis keterampilan 
pilihan. Dalam satu rombongan belajar bisa terdiri dari beberapa tingkat kelas, namun memiliki pilihan keterampilan vokasional yang sama. Walaupun satu rombongan belajar, tetapi materi akan disesuaikan dengan kemampuan masing-masing anak.

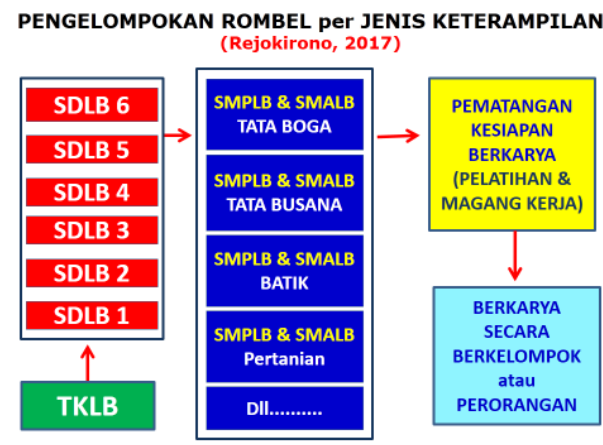

Gambar 3. Pengelompokan Rombongan Belajar (Rejokirono, 2017)

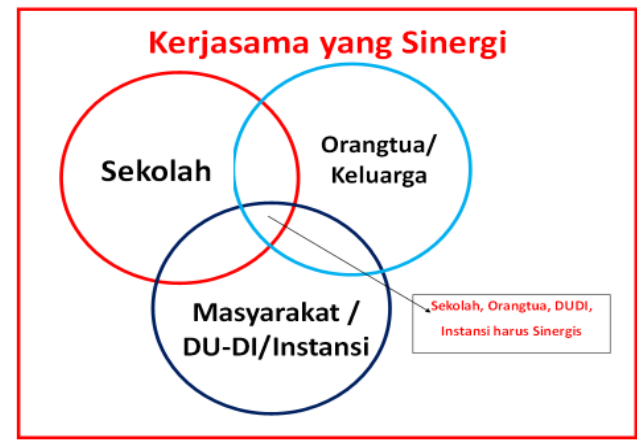

Gambar 4. Kerja sama Sekoah, Orangtua/

Keluarga dan DUDI (Rejokirono, 2017

Tampilan gambar 4 menunjukkan bahwa antara sekolah, orangtua, dan pengusaha atau DUDI harus menjalin hubungan yang sinergis, saling membantu, saling melengkapi untuk mewujudkan pembelajaran yang berkualitas dan dapat menyiapkan anak-anak tunagrahita ringan memasuki dunia kerja.

\section{Metode Penelitian}

Penelitian ini merupakan penerapan atau implementasi model manajemen pembelajaran keterampilan vokasional untuk menyiapkan anak tunagrahita memasuki dunia kerja. Model diterapkan selama satu semester yaitu pada Semester Genap Tahun Pelajaran 2017-2018 di SLB Negeri 1 Yogyakarta. Subjek penelitian adalah siswa jenjang SMPLB dan SMALB jurusan keterampilan Mencuci Motor, Tata Busana dan Membatik.

Teknik pengumpulan data dilakukan dengan cara melakukan observasi saat kegiatan pembelajaran dan wawancara kepada guru, siswa, dan orangtua untuk melengkapi informasi yang diperoleh melalui observasi. Data juga diperoleh melalui pencermatan dokumen berupa jurnal kegiatan pembelajaran mingguan yang berisi progres yang dicapai siswa dalam seminggu yang bersifat individual. Teknik pengolahan data dilakukan dengan mengakumulasi informasi yang diperoleh melalui observasi, wawancara dan pencermatan dokumen, dan mengambil kesimpulan perkembangan kesiapan siswa memasuki dunia kerja setelah mengikuti model pembelajaran ini.

\section{Hasil dan Pembahasan \\ Spesifikasi Model}

Spesifikasi model ini adalah penerapan fungsi manajemen dalam pembelajaran keterampilan vokasional yang meliputi perencanaan, pengorganisasian, pelaksanaan, dan pengendalian terkait dengan: pengelompokan rombongan belajar berdasarkan jurusan keterampilan; materi keterampilan vokasional berdasarkan analisis kurikulum dari pusat dan disesuaikan dengan masukan/kebutuhan pelaku DUDI; pendekatan proses pembelajaran tematik fungsional dengan tema-tema keterampilan; pelaksanaan PKL dan magang kerja; dan pelaksanaan kerjasama dengan pelaku DUDI. Selanjutnya masing-masing komponen dijelaskan sebagai berikut.

a Pengelompokan Rombongan Belajar

Pengelompokan kelas menggunakan model rombongan belajar per jurusan keterampilan. Pengelompokan ini didasari bahwa anak tunagrahita untuk menguasai keterampilan tertentu harus dilakukan secara berulang-ulang, memerlukan waktu yang lama, dan harus fokus pada salah satu kompetensi. Pendidikan keterampilan bagi tunagrahita ringan dilakukan agar menguasai keterampilan tertentu untuk bekal memasuki dunia kerja. Peserta didik 
SMALB dikelompokkan dalam rombongan belajar sesuai dengan jurusan keterampilan pilihannya. Kompetensi yang dilatihkan tidak berdasarkan tingkat kelas $(10,11$, atau 12), melainkan berdasarkan tingkatan kompetensi yang harus dikuasai dan bersifat individual.

\section{Materi Keterampilan}

Materi keterampilan yang diajarkan adalah materi yang sesuai dengan kebutuhan dunia kerja. Adapun hasil dari pendidikan keterampilan diharapkan dapat menjadi bekal anak memasuki dunia kerja. Selama ini banyak lulusan SMALB sudah dibekali kompetensi keterampilan tetapi kompetensi yang dimiliki belum sesuai dengan kebutuhan dunia kerja, sehingga kesulitan untuk mendapatkan kesempatan kerja. Memberikan kompetensi yang sesuai dengan kompetensi yang dibutuhkan dunia kerja dapat membantu memudahkan anak tunagrahita mendapatkan kesempatan kerja. Pendidikan dengan materi yang sudah disesuaikan dengan kebutuhan dunia kerja juga membantu proses adaptasi anak tunagrahita, karena anak merasakan banyak kesamaan antara yang dipelajari di sekolah dengan yang ada pada dunia kerja. Pemilihan materi pembelajaran juga memperhatikan potensi peserta didik dan potensi keluarga. Memperhatikan potensi peserta didik agar materi yang dilatihkan sesuai dengan kemampuan peserta didik, sedangkan memperhatikan potensi keluarga agar keluarga membantu proses pendidikan dan nantinya keterampilan yang dimiliki bisa diberdayakan di dalam keluarganya. Untuk itu dalam penyusunan kurikulum sekolah sebaiknya melibatkan pelaku dunia kerja dan orang tua atau keluarga peserta didik.

c. Pendekatan Pembelajaran Tematik

Pembelajaran dalam model ini menggunakan pendekatan tematik dengan tema-tema keterampilan. Materi mata pelajaran Pendidikan Pancasila dan Kewarganegaraan, Bahasa Indonesia, Matematika, Ilmu Pengetahuan Alam dan Ilmu Pengetahuan Sosial dipilihkan materi yang fungsional dengan keterampilan. Pelaksanaan pembelajaran Pendidikan Pancasila dan Kewarganegaraan, Bahasa Indonesia, Matematika, Ilmu Pengetahuan Alam dan Ilmu Pengetahuan Sosial disampaikan menggunakan pendekatan tematik dengan mengambil tema yang berkaitan dengan keterampilan sesuai yang dipilih peserta didik, dan diintegrasikan dalam pembelajaran keterampilan. Melalui pendekatan tematik fungsional sesuai dengan keterampilan pilihan ini bertujuan agar materi akademik dapat mendukung penguasaan kompetensi keterampilan yang dipilih peserta didik.

d. Praktik Kerja Lapangan dan Magang Kerja Pembelajaran keterampilan vokasional dilaksanakan di sekolah dan di dunia kerja. Peserta didik tunagrahita memiliki kesulitan beradaptasi di lingkungan yang baru. Setelah tamat dari SMALB, anak tunagrahita diharapkan dapat menerapkan kompetensi yang sudah dimiliki ke dunia kerja. Namun kenyataan selama ini anak kesulitan menerapkan keterampilannya di dunia kerja atau di DUDI. Salah satu penyebab dari kesulitan tersebut adalah perbedaan pengalaman yang dialami anak di sekolah dengan lingkungan kerja. Pembelajaran keterampilan di sekolah yang dibuat menyerupai dengan yang ada pada DUDI dan diberikan pengalaman PKL dan magang diharapkan memudahkan proses adaptasi anak pada dunia kerja.

e. Pemberdayaan Peran Orangtua/ Keluarga dan DUDI

Model pembelajaran keterampilan vokasional ini bisa diterapkan dengan baik harus didukung adanya kerja sama antara sekolah dengan orang tua atau keluarga peserta didik serta dengan DUDI. Kerja sama dengan orang tua atau keluarga peserta didik dibuktikan surat perjanjian kontrak layanan, sedangkan dengan DUDI dibuktikan dengan penandatanganan Memorandum of Understanding (MOU). 


\section{Seting Penerapan}

Penerapan model dilaksanakan pada Semester Ganjil Tahun Pelajaran 2018-2019 di SLB Negeri 1 Yogyakarta Jln. Bintaran Tengah Nomor 3 Yogyakarta. Model diterapkan pada jenjang SMALB kelas X, XI, dan XII Jurusan Keterampilan Otomotif, Tata Boga, dan Membatik. Seting pelaksanaan sebagai berikut:

a. Sosialisasi Model Manajemen Pembelajaran Keterampilan Vokasional untuk menyiapkan Anak Tunagrahita Memasuki Dunia Kerja. Kepala sekolah memberikan penjelasan spesifikasi model kepada seluruh guru, tenaga administrasi, orangtua siswa, dan pengusaha yang ditunjuk dan telah menjalin kerjasama dengan SLB Negeri 1 Yogyakarta. Setelah sosialisasi selanjutnya guru keterampilan menyusun program sesuai model.

b. Merencanakan pembelajaran sesuai Model Manajemen Pembelajaran Keterampilan Vokasional untuk Menyiapkan Anak Tunagrahita Memasuki Dunia Kerja. Pembelajaran direncanakan sebagai berikut: (1) Mengelompokkan rombongan belajar per jurusan keterampilan. Masingmasing jurusan menjadi satu rombongan belajar, yang di dalamnya mencakup kelas X, XI dan XII; (2) Menyusun materi dengan mempertimbangkan kurikulum pusat, tetapi tetap mempertimbangkan kesesuaian dengan kebutuhan dunia kerja, serta sesuai dengan potensi tiap-tiap siswa; (3) Menentukan tema sesuai dengan keterampilan yang sedang dibelajarkan, tema keterampilan ini dimaksudkan agar pengetahuan akademik yang dibelajarkan mendukung keterampilan yang sedang dilatihkan; (4) Membuat jadwal kegiatan pembelajaran yang melibatkan orangtua dan pengusaha secara aktif, sejak perencanaan, pelaksanaan, ataupun saat evaluasi; (5) Melaksanakan kerjasama dengan pengusaha sebagai tempat praktik atau magang kerja, dan melibatkan orangtua untuk secara aktif membantu pelaksanaan pembelajaran.

c. Melaksanakan pembelajaran sesuai Model Manajemen Pembelajaran Keterampilan Vokasional untuk Menyiapkan Anak
Tunagrahita Memasuki Dunia Kerja. Guru melaksanakan pembelajaran sesuai dengan rencana pelaksanaan pembelajaran yang telah disusun, dan membuat progres mingguan yang dituangkan dalam jurnal pembelajaran mingguan. Secara garis besar materi telah direncanakan yang dituangkan dalam silabus, tetapi pelaksanaannya akan dilakukan berdasarkan hasil progres mingguan. Setiap akhir minggu, guru memberikan catatan sampai di mana capaian masing-masing siswa, dan program apa yang harus dilatihkan untuk masingmasing anak.

d. Mengevaluasi pelaksanaan pembelajaran Model Manajemen Pembelajaran Keterampilan Vokasional untuk Menyiapkan Anak Tunagrahita Memasuki Dunia Kerja. Evaluasi dilakukan untuk mengetahui apakah model dapat diterapkan dengan baik, dan apakah ada perubahan kesiapan anak memasuki dunia kerja.

\section{Permasalahan Selama Penerapan}

Permasalahan dalam penerapan model adalah sulitnya membangun kerjasama dengan pengusaha dalam waktu cepat. Untuk itu kerjasama harus dilakukan secara bertahap mulai dari pengenalan anak, pengenalan program, dan mengajak untuk turut membantu memberikan pendidikan keterampilan kepada anak.

Permasalahan lain bahwa belum semua orangtua memiliki kesadaran bahwa keberadaannya sangat dibutuhkan dalam penerapan model pembelajaran keterampilan ini. Sebagian besar orangtua menganggap bahwa pembelajaran sudah menjadi tanggungjawab sekolah, sehingga orangtua tidak banyak membantu proses pembelajaran. Bila dikaitkan dengan kegiatan anak pasca sekolah sebagian besar orangtua juga belum memiliki kesiapan program setelah anaknya lulus.

\section{Hasil atau Bukti Penerapan}

Hasil penerapan sebagai bukti bahwa (a) tersusun rombongan belajar per jurusan keterampilan; (b) tersusun materi pembelajaran yang melibatkan orangtua, Dunia Usaha dan 
Dunia Industri; (c) tersusun perencanaan dan pelaksanaan pembelajaran menggunakan tema keterampilan; (d) terjadwal dan terlaksana kegiatan praktik kerja lapangan atau magang kerja; dan (e) adanya peran orangtua, dunia usaha dan dunia industri dalam pembelajaran.

\section{Dampak terhadap Kesiapan Anak untuk Memasuki Dunia Kerja}

Hasil penerapan juga berdampak pada kesiapan anak tunagrahita memasuki dunia kerja. Kesiapan anak ditandai dengan beberapa hal berikut: (1) anak merasa familier dengan para pengusaha; (2) anak memiliki kompetensi keterampilan vokasional yang sesuai dengan kompetensi yang dibutuhkan dunia kerja atau sesuai dengan pekerjaan yang ada di tempat kerja; (3) anak kelihatan percaya diri berada di tempat kerja; (4) anak mengikuti kegiatan praktik kerja dengan tertib mengikuti aturan yang berlaku di tempat kerja; dan (5) anak menunjukkan sikap senang dan bersemangat dalam mengikuti program magang kerja di tempat kerja.

\section{Kesimpulan dan Saran}

Penerapan model yang telah dilakukan dalam waktu satu semester pada jurusan keterampilan Otomotif, Tata Boga, dan Membatik dapat memberikan gambaran bahwa model dapat diimplementasikan dengan baik. Secara nyata dapat dilihat bahwa guru, siswa dapat mengikuti proses pembelajaran dengan baik dan tidak ada keluhan atau keberatan. Selanjutnya dari terlaksananya model pembelajaran keterampilan vokasional ini memiliki dampak yang berarti bagi siswa yaitu meningkatnya kesiapan anak memasuki dunia kerja. Dengan demikian dapat disimpulkan bahwa model tersebut terbukti dapat diterapkan dengan baik di SLB Negeri 1 Yogyakarta dan dapat meningkatkan kesiapan anak dalam memasuki dunia kerja.

Model dapat diterapkannya dengan baik di SLB Negeri 1 Yogyakarta dan dapat memberikan solusi terhadap permasalahan lulusan yang tidak memiliki keterampilan dan sulit memasuki dunia kerja, diyakini dapat juga diterapkan di sekolah lain yang menyelenggarakan pendidikan bagi anak tunagrahita. Selanjutnya diharapkan model manajemen pembelajaran keterampilan vokasional untuk menyiapkan anak tunagrahita memasuki dunia kerja dapat segera diimplementasikan pada SLB-SLB di Daerah Istimewa Yogyakarta. Penerapan dapat dilaksanakan secara bertahap sesuai dengan kesiapan tiap-tiap sekolah. Sekolah juga diharapkan dapat membangun jejaring dengan para pengusaha sejak awal untuk mendukung terlaksananya pembelajaran keterampilan yang memiliki kesesuaian antara kompetensi yang dibelajarkan dengan kompetensi yang dibutuhkan pengusaha. Orangtua juga diberikan pelatihan agar dapat menyiapkan kegiatan atau program untuk anaknya setelah lulus sekolah.

\section{Daftar Rujukan}

American Psichiatric Assosiation (2013). Diagnostic and Statistical Manual of Mental Disorders (DSM-5). Arlington: British Library.

Djoko Santoso. (2011). Sekolah harap peka terhadap kebutuhan dunia kerja. Majalah Diknas, No. 03/I/ Agustus - September 2010 .

Fasli Jalal. (2011). Sekolah harap peka terhadap kebutuhan dunia kerja. Majalah Diknas, No. 03/I/ Agustus - September 2010 .

Fasich. (2011). Sekolah harap peka terhadap kebutuhan dunia kerja. Majalah Diknas, No. 03/I/ Agustus - September 2010.

Haerana. (2016). Manajemen Pembelajaran Berbasis Standar Proses Pendidikan. Teori dan Aplikasi. Yogyakarta: Media Akademi.

Muhammad Yaumi. (2012). Pembelajaran berbasis Multiple Intelligences. Jakarta: Dian Rakyat.

Muhammad Yusuf, Sunardi \& Abdurrahman, M. (2003). Pendidikan bagi Anak dengan Problema Belajar. Solo: Tiga Serangkai.

Peraturan Gubernur DIY. (2010). Tugas pokok dan fungsi Sekolah Luar Biasa Negeri. Yogyakarta: Pemda DIY. 
Rejokirono. (2015). Menyiapkan Anak Tunagrahita Memasuki Dunia Kerja melalui Praktek Kerja Lapangan (PKL) dan Magang Kerja. Proceeding International Seminar Special Education (ISSE). Surabaya: Unesa.

Smith, M. B., Ittenbach, R. F., \& Patton, J. R. (2002). Mental Retardation. 6th ed. New Jersey: Merrill Prentice Hall.

Syaifurahman \& Tri Ujati. (2013). Manajemen dalam Pembelajaran. Jakarta: Indeks.

Yulk, G. (1994). Leadership in Organization: Third edition. New Jersey: Prentice-Hall. 